\title{
IMPLEMENTATION OF MOBILE VIRTUAL LABORATORY: CONTRIBUTORY FACTORS IN A DEVELOPING COUNTRY
}

Ogundipe Oluwole, Goga Nicolae, Omotosho Olawale, Awodele Samuel Department of Computer Science, Babcock University, llishan-Remo, Ogun State, Nigeria ogundipe@gmail.com

University of Groningen, The Netherlands or Politenica Bucharest

$$
\text { n.goga@rug.nl }
$$

Department of Computer Science, Babcock University, llishan-Remo, Ogun State, Nigeria ojomotosho@yahoo.com

Department of Computer Science, Babcock University, llishan-Remo, Ogun State, Nigeria delealways@yahoo.com

\begin{abstract}
The growing availability of mobile devices across developing countries and coupled with increase awareness of mobile learning as well as the use of mobile devices for laboratory practical warrant the exploration of its wider application in learning. This study explored the factors that contribute to the successful implementation of mobile virtual laboratory in a developing country. A Nigerian higher institution was selected because of its peculiar location in a rural area and was important in the evaluation of the Internet penetration in rural areas of Nigeria for $\mathrm{m}$-Learning. A designed questionnaire for need analysis was distributed to 132 consented participants and the resulting data were analysed using SPSS-21. The study shows that the term mobile learning was not too new to majority of the learners as (44.7\%) indicated that they had heard about it. However majority of the respondents $(78.8 \%)$ had never heard about Mobile Virtual Laboratories. MTN data plan was mostly used for Internet because of its $\mathrm{N} 1000$ (5 US dollars) data plan. Again, majority of the respondents used Blackberry (57\%) and Android phones (32\%). Based on the findings in this study, the network, data plan, device type and learners awareness were important factors characterising the needs and choices of learners. Overall, uptake of mobile learning will be easy and enhanced if determinants of learners needs and choice as identified in this study are considered in the implementation of mobile virtual laboratory in a developing country.
\end{abstract}

\section{Keywords}

Contributor factors; Cross-platform; e-Learning; Learning objects; m-Learning; Mobile Virtual Laboratories; Virtual Laboratories

\section{Academic Discipline And Sub-Disciplines}

Computer Science

\section{SUBJECT CLASSIFICATION}

Mobile Learning

\section{TYPE (METHOD/APPROACH)}

Survey/Interview

\section{Council for Innovative Research}

\author{
Peer Review Research Publishing System
}

\section{Journal: INTERNATIONAL JOURNAL OF COMPUTERS \& TECHNOLOGY}

Vol 14 . No. 5

www.ijctonline.com, editorijctonline@gmail.com 


\section{INTRODUCTION}

Ubiquitous technologies are making it possible for learners not to be bound in fixed classrooms for learning purposes. Such "anytime", "anywhere" computing platforms have ignited a paradigm shift from e-learning models to m-learning models (Luis de Marcos et al., 2006). Hence increasing research attention is unfolding in the area of m-learning from industrialists, researchers, educationist and policy makers (Ayala and Castillo 2008; Traxler, 2007). As a consequence, $m$ learning has been variously defined. While considering a mobile device as an enabler of learner mobility, Traxler (2007) defined m-learning as learning which takes place at anytime in anyplace using a mobile device. Similarly, Luis de Marcos et al. (2006) defined m-learning as a form of e-learning which employs wireless, tiny, handheld and portable devices to extend and deliver learning to learners. A view earlier expressed by Brown (2005) emphasized that m-learning is elearning which uses mobile devices to deliver learning. It is evident from the various definitions that $m$-learning is a form of e-learning which takes place at anytime in any place using mobile devices.

The mobile telephone industry has seen unprecedented growth in developing countries over the last decade. According to International Telecommunication Union ITU (2007), Africa experienced a compound annual growth rate in mobile subscription of $49.4 \%$ as compared to Europe's 17\% between 2002 and 2007. By 2007 the ITU posited the World percentage of mobile phone to total number of telephone subscribers at $72.6 \%$. Africa had $89.7 \%$ of its total telephone subscribers as being from mobile phone users.

Table 1 NCC - Monthly Subscriber data (May 2013-April 2014)

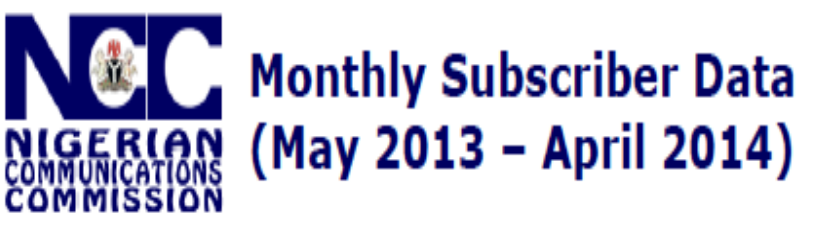

\begin{tabular}{|c|c|c|c|c|c|c|c|c|c|c|c|c|c|}
\hline & OPERATOR & Apr '14 & Mar '14 & Feb '14 & $\operatorname{Jan} 14$ & $\operatorname{Dec}^{\prime} 13$ & Nov'13 & Oct'13 & Sep 13 & Aug 13 & Jul' 13 & Jun '13 & May' 13 \\
\hline \multirow{4}{*}{$\begin{array}{l}\text { Connected } \\
\text { Lines }\end{array}$} & Mobile (GSM) & $172,913,989$ & $168,595,831$ & $167,371,945$ & $162,719,517$ & $159,758,538$ & $155,938,379$ & $156,129,961$ & $158,239,230$ & $150,891,051$ & $153,665,438$ & $164,642,742$ & $150,888,100$ \\
\hline & Mobile (CDMA) & $4,076,933$ & $4,083,672$ & $7,620,525$ & $7,667,314$ & $7,684,028$ & $11,241,343$ & $11,341,578$ & $11,307,307$ & $11,344,675$ & $11,462,206$ & $14,250,514$ & $14,217,718$ \\
\hline & Fixed Wired/Wireless & 328,388 & 327,524 & $2,238,458$ & $2,238,894$ & $2,233,981$ & $2,459,530$ & $2,458,077$ & $2,414,988$ & $2,362,487$ & $2,370,287$ & $2,452,697$ & $2,450,260$ \\
\hline & Total & $177,319,310$ & $173,007,027$ & $177,230,928$ & $172,625,725$ & $169,676,545$ & $169,639,252$ & $169,929,616$ & $171,961,525$ & $164,598,213$ & $167,497,931$ & $181,345,95$ & $167,556,078$ \\
\hline \multirow{5}{*}{ Active Lines } & Mobile (GSM) & $126,958,904$ & $124,884,842$ & $126,246,648$ & $125,173,177$ & $124,841,315$ & $121,000,000$ & $119,101,719$ & $118,470,236$ & $109,846,288$ & $111,866,933$ & $117,412,36$ & $117,765,609$ \\
\hline & Mobile (CDMA) & $2,256,612$ & $2,039,391$ & $2,398,581$ & $2,421,970$ & $2,404,777$ & $2,377,790$ & $2,423,746$ & $2,438,590$ & $2,440,934$ & $2,519,602$ & $2,567,177$ & $2,593,253$ \\
\hline & Fixed Wired/Wireless & 172,876 & 172,963 & 357,612 & 365,433 & 360,537 & 362,434 & 362,549 & 362,392 & 375,217 & 373,871 & 382,678 & 389,892 \\
\hline & Total & 29,391, & $127,097,196$ & $129,002,84$ & $127,960,580$ & $127,606,6$ & $123,740,224$ & $121,888,014$ & $121,271,218$ & $112,271,439$ & $114,760,406$ & $120,362,2$ & $120,748,754$ \\
\hline & Teledensity & 92.42 & 90.78 & 92.14 & 91.40 & 91.15 & 88.39 & 87.06 & 86.62 & 80.47 & 81.97 & 85.97 & 86.25 \\
\hline
\end{tabular}

From the above data table from Nigerian Communication Commission (NCC), the ratio of mobile phone subscribers to fixed telephones in April, 2014 stood at about 747 to 1. By April 2014, the mobile tele-density in Nigeria was $92.42 \%$ (NCC, 2014). These statistics present a scenario of high mobile phone in the developing countries like Nigeria. This proliferation presents a fertile ground for M-Learning growth especially if appropriate mobile networking technologies are available to learners.

The justification of this study stems from the realization that in Africa, electronic learning is constrained by limited availability of Internet connectivity, lack of or intermittent power supply, low Internet bandwidth, lack of Information and Communication Technology (ICT) skills and limited financial resources (Farrell and Isaacs, 2007) among others. These constraints can be overcome by mobile learning (Brown, 2005). The following factors that impede the implementation of $\mathrm{mLearning}$ are: learner acceptance, Small screen size, lack of data imputing capability, low storage, low bandwidth, limited processor speed, short battery life, software issues and interoperability and finally lack of standardization (Manair and Bennett, 2007;Abu-Al-Alish and Love, 2013; Sarrab et al., 2012).

Several research works have been carried out in developing countries which have identified that the available mobile devices with different capabilities are positive pointers to the readiness of the educators and students to accept the new trend in education (Osang et al., 2010; Oyerinde, 2014; Asabere, 2013). Factors that lead to the successful adoption and usage of one technology in one country do not necessarily apply to other countries. This is because of the different environmental factors. Osang et al., (2010) posited that in Nigeria factors such as learning environment, perception of the educators, motivation of the educators, security challenges, cost of bandwidth to support mobile learning are parameters that should be considered greatly. The afore- mentioned issues provided the impetus for setting out this study to explore 
the factors that are cardinal to the implementation of mobile virtual laboratory in a developing country.

\section{METHODOLOGY}

This is a cross-sectional, descriptive questionnaire based study on need assessment analysis. One hundred and fifty targeted learners were purposively selected and 132 consented participants completed the questionnaire. The evaluation was carried out using students from Ambrose Alli University, Ekpoma - Nigeria. This institution was selected because it is located in a rural area and this requirement was important in the evaluation of the Internet penetration in rural areas of Nigeria for m-Learning.

The information assessed included socio-demographic data of respondents, the available mobile network, the Internet data plan and the mobile device mostly used by the students, the learners' awareness of mobile learning was also evaluated.

At the beginning of the experiment, participants had a one-hour orientation session about how to download and use the mobile virtual laboratory components. In the orientation session, each student was informed of the study and briefed on the research instrument.

After returning the questionnaires, the data was processed in preparation for analysis. Data were checked to ensure that there were no inconsistencies and inaccuracies. However, care was taken during survey design, to ensure that clear instructions are given. Each questionnaire was given a unique identifier to avoid duplicate entries during analysis. Unstructured (open ended) responses were categorized into mutually exclusive groups and coded.

The Statistical Package for Social Sciences version 21 (SPSS-21) was used to conduct the statistical analysis. The researcher used the Friedman's test to determine test of significance.

RESULTS

Table 2: Demographic characteristics

\begin{tabular}{|c|c|c|}
\hline FACTORS/VARIABLES & FREQUENCY(N=132) & $\begin{array}{l}\text { PERCENT } \\
(\%)\end{array}$ \\
\hline \multicolumn{3}{|l|}{ Year } \\
\hline 100 LEVEL & $x_{1}$ & 34.1 \\
\hline 200 LEVEL & 30 & 22.7 \\
\hline 300 LEVEL & 15 & 11.4 \\
\hline 400 LEVEL & 16 & 12.1 \\
\hline 500 LEVEL & 22 & 16.7 \\
\hline 600 LEVEL & 2 & 1.5 \\
\hline MSC/GRADUATE & 2 & 1.5 \\
\hline \multicolumn{3}{|l|}{ SEX } \\
\hline MALE & 64 & 48.5 \\
\hline FEMALE & 68 & 51.5 \\
\hline \multicolumn{3}{|l|}{ PROGRAMMES } \\
\hline $\begin{array}{l}\text { Faculty of Natural Sciences } \\
\text { (FNS) }\end{array}$ & 91 & 68.9 \\
\hline $\begin{array}{l}\text { Faculty of Mgt Science (MGT } \\
\text { SC) }\end{array}$ & 37 & 28.0 \\
\hline ART & 4 & 3.0 \\
\hline
\end{tabular}

\section{Source: Field survey (2014)}

The above Table 2 reveals the demographic characteristics of the respondent of this study. Majority of the respondents (34.1\%) are in Year 1 (i.e. 100 level). The female participants are sixty-eight with the proportion of $51 \%$ and the remaining proportion of $48.5 \%$ are male. This implies that females are slightly more than male respondents. For the programme of study $(68.9 \%)$ of the participants were from the Faculty of Natural Sciences (FNS) and 28\% from the Faculty of Management Science with the lowest number of respondents $4 \%$ from Faculty of Arts. 
Table 3: Responses to need analysis

\begin{tabular}{|c|c|c|}
\hline FACTORS/VARIABLES & FREQUENCY(N=132) & $\begin{array}{l}\text { PERCENT } \\
(\%)\end{array}$ \\
\hline \multicolumn{3}{|l|}{ DATA PLAN } \\
\hline HOURLY & 1 & 0.8 \\
\hline DAILY & 11 & 8.3 \\
\hline WEEKLY & 11 & 8.3 \\
\hline MONTHLY & 104 & 78.8 \\
\hline OTHERS & 5 & 3.8 \\
\hline \multicolumn{3}{|l|}{ COST } \\
\hline$<\mathbb{N 1 0 0 0}$ & 15 & 11.4 \\
\hline N1000-2000 & 100 & 75.8 \\
\hline$>\mathbb{N} 2000$ & 17 & 12.9 \\
\hline \multicolumn{3}{|l|}{ TOUCH } \\
\hline YES & 97 & 73.5 \\
\hline NO & 35 & 26.5 \\
\hline SITE VISIT & & \\
\hline YES & 95 & 72.0 \\
\hline No & 37 & 28.0 \\
\hline \multicolumn{3}{|l|}{$\begin{array}{l}\text { HEARD OF MOBILE } \\
\text { LEARNING }\end{array}$} \\
\hline YES & 53 & 40.2 \\
\hline NO & 79 & 59.8 \\
\hline \multicolumn{3}{|l|}{$\begin{array}{l}\text { HEARD OF MOBILE } \\
\text { VIRTUAL } \\
\text { LABORATORY }\end{array}$} \\
\hline YES & 18 & 13.6 \\
\hline NO & 114 & 86.4 \\
\hline \multicolumn{3}{|l|}{$\begin{array}{l}\text { INTENDED COURSE } \\
\text { IN MVL }\end{array}$} \\
\hline SCIENCE & 62 & 47.0 \\
\hline OTHERS & 23 & 17.4 \\
\hline NONE & 47 & 35.6 \\
\hline \multicolumn{3}{|l|}{$\begin{array}{l}\text { USEFULNESS OF } \\
\text { LEARNING } \\
\text { MATERIALS }\end{array}$} \\
\hline USEFUL & 126 & 95.5 \\
\hline
\end{tabular}




\begin{tabular}{|c|c|c|}
\hline NOT USEFUL & 4 & 3.0 \\
\hline NO RESPONSE & 2 & 1.5 \\
\hline \multicolumn{3}{|l|}{$\begin{array}{l}\text { INTEREST IN } \\
\text { FURTHER } \\
\text { RESEARCH ON MVL }\end{array}$} \\
\hline YES & 97 & 73.5 \\
\hline $\mathrm{NO}$ & 24 & 18.2 \\
\hline NO RESPONSE & 11 & 8.3 \\
\hline \multicolumn{3}{|l|}{ MOBILE NETWORKS } \\
\hline GLO & 33 & 25.0 \\
\hline MTN & 73 & 55.3 \\
\hline ETISALAT & 2 & 1.5 \\
\hline AIRTEL & 6 & 4.5 \\
\hline MULTIPLE & 18 & 13.6 \\
\hline \multicolumn{3}{|l|}{ PHONE MAKE } \\
\hline HTC & 2 & 1.5 \\
\hline GIONEE & 2 & 1.5 \\
\hline SONY ERICSSON & 5 & 3.8 \\
\hline SAMSUNG & 10 & 7.6 \\
\hline NOKIA & 14 & 10.6 \\
\hline TECHNO & 23 & 17.4 \\
\hline BLACKBERRY & 76 & 57.6 \\
\hline
\end{tabular}

Source: Field survey (2014)

The Table 3. above indicates that the highest proportion of the participants of this study i.e. (78.8\%) supports the monthly Data Plan and only seven of the respondents with a proportion of $(0.8 \%)$ subscribed to the hourly plan and the remaining $(11.4 \%)$ of the participants supports daily, weekly and other types of Data Plan. $(40.2 \%)$ had previously heard of mobile learning while $(59.8 \%)$ had not heard of mobile learning. This means that a large number of them had previous knowledge of mobile learning. For mobile virtual laboratories (13.6\%) had heard of Mobile Virtual Laboratory (MVL) while (86.4\%) had 
not heard of MVL, which indicates that MVL was new to majority of the respondents. (18.2\%) of the respondents indicated that they were not interested in further research on MVL while $(73.5 \%)$ indicted that they will be interesting in further research on MVL. The Internet service provider mostly used by the respondents on their mobile device was MTN, by $55 \%$ of the respondents followed by GLO (25\%) then Airtel (4.5\%) and Etisalat (1.5\%).

Table 4. Crosstabs showing relationship between cost and phone make

\begin{tabular}{|c|c|c|c|c|c|c|c|c|c|}
\hline \multicolumn{10}{|c|}{ COST * MAKECrosstabulation } \\
\hline \multicolumn{10}{|l|}{ Count } \\
\hline & & \multicolumn{7}{|c|}{ MAKE } & \multirow[t]{2}{*}{ Total } \\
\hline & & HTC & GIONEE & $\begin{array}{c}\text { SONY } \\
\text { ERICSSON }\end{array}$ & SAMSUNG & NOKIA & TECHNO & BLACKBERRY & \\
\hline \multirow{3}{*}{ COST } & 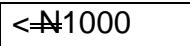 & 0 & 0 & 0 & 0 & 8 & 4 & 3 & 15 \\
\hline & A1000-2000 & 0 & 1 & 3 & 8 & 6 & 16 & 66 & 100 \\
\hline & 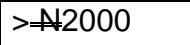 & 2 & 1 & 2 & 2 & 0 & 3 & 7 & 17 \\
\hline \multicolumn{2}{|l|}{ Total } & 2 & 2 & 5 & 10 & 14 & 23 & 76 & 132 \\
\hline
\end{tabular}

Chi-square value $=57.394, \mathrm{df}=12, \mathrm{p}$-value $=0.000$

From Table 4. above it indicates that there is a significant relationship between cost and Make of phone since the $p$-value is less than $\alpha(0.000)$ with the chi-square ratio of 57.394 with $\mathrm{df}=12$. This showed that most of the students use a blackberry because of the $\$ 1000$ monthly plan that was most affordable.

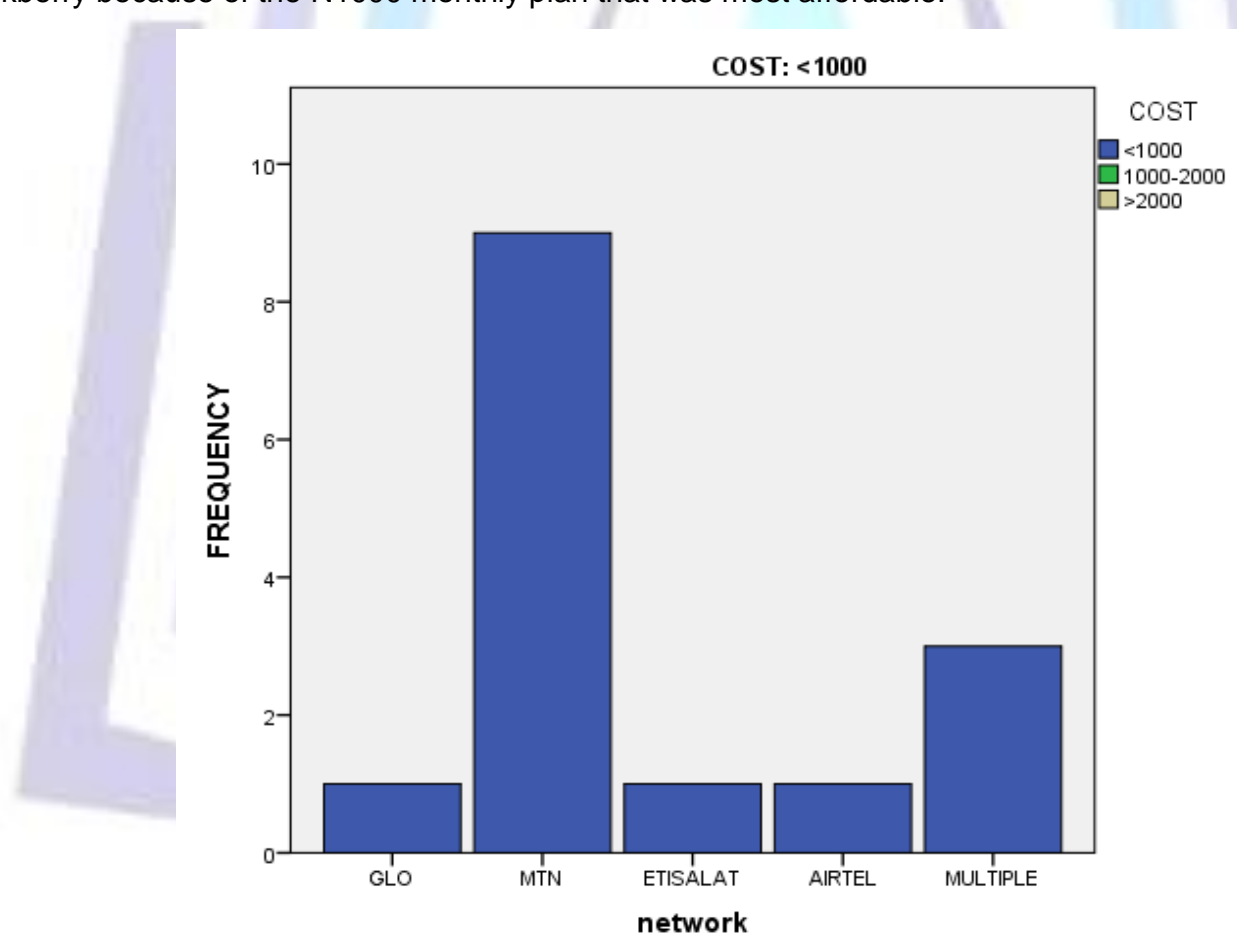

Figure 2: Bar chat showing the mobile networks against cost $>N 1,000$

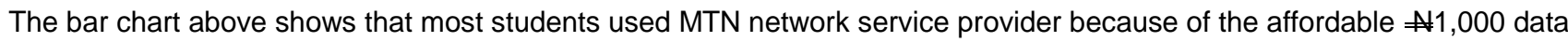
plan they provided.

\section{DISCUSSION}

The purpose of this study was to present the findings regarding the perceived benefits and barriers to implementing $\mathrm{m}$ Learning using Mobile Virtual Laboratory (MVL). It considered the cost of existing infrastructure, mobile devices, preferred network, and learner factors like informed choice and willingness to use MVL for learning.

The study shows the different types of mobile devices owned by the students; for instance about two-thirds owned blackberry, and about one-third owned Android mobile devices. This indicates that students already have the necessary phone capabilities to support mobile learning, which is in line with the statistics made available by NCC (2014), which indicated that the mobile tele-density in Nigeria was $92.42 \%$. The availability and use of mobile devices like Blackberry and Android will certainly enhanced the quality of the learners content. 
Another important area covered by the research was assessing the learners' awareness of mobile learning and mobile virtual laboratory. From the responses, almost half of the respondents had previous knowledge of $m$-Learning and more half of them had not heard of mobile learning. These findings indicate that mobile learning was not entirely new to the students. A contrary finding was observed with respect to Mobile Virtual Laboratory as over three-quarter of the respondents had never heard of mobile virtual laboratory while less than one-quarter had heard of MVL. As it is Mobile Virtual Laboratory was new to most of the respondents. This finding supports the works of other researchers (Sarrab et al., 2012; Abu-Al-Aish and Love, 2013) and underscores the need for students to be properly oriented in order to effectively participate in its use for learning as well as enhance learner acceptance.

Furthermore, it can be seen from this study that almost three quarters of respondents were interested in further research on MVL, while less than a quarter were not interested in further research. This observation shows that many of the respondents were interested in participating in MVL experiments. Thus, it is an indicator that the students were ready to key into the new mode of learning showing learner acceptance of this new mode of learning. This interest can be further enhanced through motivation, which is in line with recommendations from earlier research (Abu-Al-Aish and Love, 2013; Liu et al., 2010).

Beyond the above, the study observed that over three quarters of the respondents subscribe to the monthly data plan because of its affordability. There is a significant relationship between the cost of the data plan and the make of the mobile device as over half of the students used blackberry for the N1,000 MTN data plan because it is the provider with the cheapest and most flexible data plan. This further supports the fact that the cost of data plan and type of mobile device are important factors for the effective implementation of MVL.

Overall, the study identified factors such as network service provider, data plan, device type and learners awareness that can guide stakeholders when considering implementation of MVL. Similarly, mobile learning was not an entirely new concept, nevertheless majority have never heard about MVL but they showed interest in further research in this area. Evidently, the importance of using MVL mode of learning especially in institutions where they don't have immediate access to expensive laboratory equipment cannot be over emphasized. However, this study identified a number of contributory factors (including network service provider, data plan, device type and learners awareness) as key to the successful implementation of mLearning in developing countries.

\section{Limitations of the study}

The survey instrument was only administered in one university. Responses from more universities could possibly enrich the result beyond what was obtained.

\section{CONCLUSION}

Mobile learning is the future of education in Nigeria and many developing countries particularly because of the improvement in Internet penetration and the availability of mobile devices.

This study identified the factors that can guide stakeholders considering the implementation of mLearning. Given that $\mathrm{mLearning}$ uptake will be easy and enhanced if planning is done with the consideration of learner factors like informed choices, convenience, mobile device, preferred network, cost existing infrastructure amongst others are considered. This paves way for other researchers to build or develop tools for other academic levels from secondary education level to the tertiary level. Mobile Virtual Laboratory implementation strategies require policy makers to ensure that various stakeholders take advantage and explore the opportunities in reaching out to rural communities. We also advocate creation of awareness on MVL.

\section{Future works}

Future work would be in the area of measurement of the possible impact that can be achieved with the proposed approach in terms of administering the survey instrument in two other institutions of higher learning and then carry out a comparative analysis of the result.

\section{REFERENCES}

[1] Abu-Al-Aish, A. and Love, S. (2013) factors Influencing Students' Acceptance of M-Learning: An Investigation in Higher Education. The International review of Research in Open and Distance Learning (IRRODL).

[2] Asabere, N. (2013) Benefits and Challenges of Mobile Learning Implementation: Story of Developing Nations. "International Journal of Computer Applications" (0975-8887) Volume 73-No.1.

[3] Ayala, G., and Castillo, S. (2008, March 23-26). Towards Computational Models for Mobile Learning Objects. Paper presented at the Fifth IEEE International Conference on Wireless, Mobile, and Ubiquitous Technology in Education (WMTE'05), Tokushima, Japan

[4] Brown, H. (2005). Towards a Model for m-Learning in Africa. International Journal on E-learning, 4(3), $299-315$.

[5] Farrell, G., and Isaacs, S. (2007). Survey of ICT and Education in Africa. A Summary Report Based on 53 Country Surveys. Retrieved November 10, 2013, from http://akgul.bcc.bilkent.edu.tr/egitim/ict-africa-survey.pdf.

[6] International Telecommunication Union (2007). World Information Society Report 2007. Geneva: ITU. Retrieved May 18, 2014 from http://www.itu.int/osg/spu/publications/worldinformationsociety/2007/WISR07_full-free.pdf. 
[7] Liu, Y. and Han, S. and Li, H. (2010) "Understanding the factors driving m-learning adoption: a literature review" Campus-Wide Information Systems Vol. 27 No. 4, 2010 pp. 210-226 q Emerald Group Publishing Limited 1065-0741 DOI 10.1108/10650741011073761

[8] Luis de Marcos, H. R. J., Gutiérrez A.J., Pagés C., and Martínez, J.J. (2006). Implementing Learning Objects Repositories for Mobile Devices. Retrieved October 24, 2013, from http://ftp.informatik.rwthaachen.de/Publications/CEUR-WS/Vol-208/paper04.pdf

[9] Maniar, N. and Bennet, E (2007) “Media influence on m-learning”, Proceedings of VideoFunet Conference, Tampere, Finland.

[10] NCC (2014) Nigeria Communications Commission, Retrieved August 09, 2014, from http://www.ncc.gov.ng/index.php?option=com_contentandview=articleandid=125:art-statistics-subscriberdataandcatid=65: cat-web-statisticsandltemid $=\overline{7} 3$

[11] Osang, F. ; Ngole, J.; Tsuma C. (2010) Prospects and Challenges of Mobile Learning Implementation in Nigeria: Case study National Open University of Nigeria (NOUN) "International Conference on ICT for Africa 2013, February 20-23, Harare, Zimbabwe"

[12] Oyerinde, $\mathrm{O}$ (2014) A review of Challenges Militating Against Sucessful e-Learning and M-Learning Implementations in Developing Countries. "International Journal of Science and Advanced Technology" (ISSN 2221-8386)

[13] Sarrab, M.; Elgamel, L.; Aldabbas, H. (2012) Mobile Learning (M-Learning and Educational Environments). International Journal of Distributed and Parallel Systems (IJDPS) Vol. 3, No.4.

[14] SPSS for Windows 21.0 (Computer software). (2012). Chicago, IL: SPSS Inc.

[15] Traxler, J. (2007). Defining, Discussing, and Evaluating Mobile Learning: The moving finger writes and having writ.... International Review of Research in Open and Distance Learning, 8(2), 1-12. 